\title{
Induction of Cell Proliferation by Fibroblast and Insulin-Like Growth Factors in Pure Rat Inner Ear Epithelial Cell Cultures
}

\author{
J. Lisa Zheng, Christian Helbig, and Wei-Qiang Gao \\ Department of Neuroscience, Genentech, Incorporated, South San Francisco, California 94080
}

Proliferation of supporting cells in the inner ear is the early major event occurring during hair cell regeneration after acoustic trauma or aminoglycoside treatment. In the present study, we examined the possible influence of 30 growth factors on the proliferation of pure rat utricular epithelial cells in culture. Utricular epithelial sheets were separated and partially dissociated from early postnatal rats via a combined enzymatic and mechanical method. The cultured utricular epithelial cells expressed exclusively epithelial cell antigens, but not fibroblast, glial, or neuronal antigens. With tritiated thymidine incorporation assays, we found that several fibroblast growth factor (FGF) family members, insulin-like growth factor-1 (IGF-1), IGF-2, transforming growth factor- $\alpha$ (TGF- $\alpha$ ), and epidermal growth factor (EGF), stimulated proliferation of the utricular epithelial cells. In contrast, neurotrophins and other growth factors did not elicit any detectable mitogenic effects. Among all of the growth factors examined, FGF-2 was the most potent mitogen. When FGF-2 was added in combination with IGF-1 or TGF- $\alpha$ to the medium, combined effects were seen. These results were confirmed with BrdU immunocytochemistry. Thus, the present culture system provides a rapid and reliable assay system to screen novel growth factors involved in proliferation of mammalian inner ear supporting cells. Furthermore, immunostainings revealed that the cultured utricular epithelial cells expressed FGF and IGF-1 receptors, and utricular hair cells produced FGF-2 in vivo. The addition of neutralizing antibodies against FGF-2 or IGF-1 to the cultures significantly inhibited the utricular epithelial cell proliferation. This work suggests that FGF-2 and IGF-1 may regulate the proliferation step during hair cell development and regeneration.

Key words: hair cell regeneration; supporting cells; proliferation; differentiation; utricle; vestibular; growth factors; FGF; IGF
Over the past several years, it has been well demonstrated that lower vertebrate and avian animals have a capacity to regenerate new inner ear hair cells (Cotanche, 1987; Corwin and Cotanche, 1988; Ryals and Rubel, 1988; Jones and Corwin, 1996). A certain degree of hair cell regeneration or repair also has been reported in mammalian inner ear structures (Forge et al., 1993; Warchol et al., 1993). Although recent studies have suggested a direct conversion of some supporting cells into hair cells in both lower vertebrates (Adler et al., 1996; Jones and Corwin, 1996) and mammals ( $\mathrm{Li}$ and Forge, 1996), proliferation of supporting cells in both avian (Cotanche and Lee, 1994) and mammalian (Warchol et al., 1993) inner ear epithelia seems to be the first major step between degeneration of hair cells because of acoustic trauma or exposure to ototoxins and regeneration of new hair cells. Because the supporting cells in the inner ear epithelium are most likely the progenitors for the hair cells (Corwin and Cotanche, 1988; Balak et al., 1990; Rapheal, 1992; Weisleder and Rubel, 1992), the proliferation of the supporting cells is critical for the replacement of the lost hair cells and the supporting cells that are capable of converting into new hair cells. Understanding the proliferation process of the inner ear supporting cells will shed light on the mechanisms for hair cell regeneration and will be helpful to us in

\footnotetext{
Received Aug. 8, 1996; revised Oct. 16, 1996; accepted Oct. 21, 1996.

We thank Dr. Heidi Phillips for her encouragement and support, Drs. Arnon Rosenthal and John Winslow for helpful discussions, and Janet Valverde for assistance in immunocytochemistry. We also thank Dr. Tracey Shors for critical reading of this manuscript and Wayne Anstine for preparation of these figures.

Correspondence should be addressed to Dr. Wei-Qiang Gao, Department of Neuroscience, MS \#72, Genentech, Incorporated, 460 Point San Bruno Boulevard, South San Francisco, CA 94080

Copyright (C) 1996 Society for Neuroscience $0270-6474 / 96 / 170216-11 \$ 05.00 / 0$
}

eventually finding therapeutic agents for treatment of hearing and balance impairments.

Growth factors play a very important role during cell proliferation and differentiation, as documented in hemopoietic and nervous systems (Anderson, 1989; Cattaneo and McKay, 1990; Gao et al., 1995; Ghosh and Greenberg, 1995; Vicario-Abejon et al., 1995). Some growth factors may act as both a mitogen and a differentiating factor; some regulate only one of the developmental steps (e.g., a sole mitogen, differentiating, or survival factor); others may work in a sequential way to control the final cell phenotype. The determination of the possible influences of growth factors on proliferation and differentiation of progenitor cells usually is done in cell cultures.

Recent studies using inner ear organ cultures have indicated that TGF- $\alpha$ and EGF are mitogens for the inner ear supporting cells (Lambert, 1994; Yamashita and Oesterle, 1995). However, cell counts of dividing cells in the organ cultures and the interpretation of the results are technically difficult because of the complexity of multiple cell types that exist in these cultures. First, proliferation of other cell types, rather than epithelial cells, may disturb the cell counts. Second, the mitotic index could vary from one domain to another domain of the inner ear epithelium because of accidental damage during dissections. The quantitative analysis for cell proliferation in the inner ear epithelium usually has to be performed in plastic sections. Because there are only a few dividing cells per utricle (Yamashita and Oesterle, 1995), a large sample of tissues is required for the comparison between the control and the experimental groups. Consequently, this becomes a rate-limiting step for studying a larger number of growth factors. Finally, it is hard to interpret whether the effect of the growth factors is direct or indirect on supporting cells. A way to overcome 
these problems might be via development of pure inner ear epithelial cell cultures (Corwin et al., 1995).

In the present study, we have developed a rapid, reliable tritiated thymidine assay for measurement of the progenitor cell DNA synthesis in purified, partially dissociated postnatal rat inner ear epithelial cell cultures. Using this rapid, convenient assay, we examined the effects of a panel of 30 growth factors on the proliferation of utricular supporting cells. These included known and commonly studied mitogens and differentiating and survival factors in the nervous system. We report here that several FGF family members, IGF-1, IGF-2, TGF- $\alpha$, and EGF, are mitogens for the utricular supporting cells. Among them, FGF-2 is the most potent mitogen. Furthermore, additive effects were observed when FGF-2 was added in combination with IGF-1 or TGF- $\alpha$ in the cultures. These results were confirmed by BrdU immunocytochemistry. In contrast, neurotrophins and other growth factors examined did not exert any detectable mitogenic effects. Moreover, antibody labeling revealed that utricular hair cells produced FGF-2 in vivo, and utricular epithelial cells expressed FGF and IGF-1 receptors in vitro. Inclusion of neutralizing antibodies against FGF-2 or IGF-1 in the medium reduced utricular epithelial cell proliferation. Thus, these results suggest that FGF-2 and IGF-1 may be candidate molecules regulating proliferation of the inner ear supporting cells. In particular, FGF-2 could be a physiological growth factor during regeneration of new hair cells following challenge by aminoglycosides or noise.

\section{MATERIALS AND METHODS}

Preparation of epithelial cell cultures. Utricular epithelial sheets were separated from postnatal day 4-5 (P4-P5) Wistar rats with $0.5 \mathrm{mg} / \mathrm{ml}$ thermolysin (Sigma, St. Louis, MO) in calcium- and magnesium-free HBSS for $30 \mathrm{~min}$ at $37^{\circ} \mathrm{C}$, based on the method reported previously (Corwin et al., 1995). Then the epithelial sheets (see Fig. 1A) were incubated in a mixture of $0.125 \%$ trypsin and $0.125 \%$ collagenase for 8 min at $37^{\circ} \mathrm{C}$. The enzyme activity was inactivated with a mixture of $0.005 \%$ soybean trypsin inhibitor (Sigma) and $0.005 \%$ DNase (Worthington, Freehold, NJ) before being pipetted up and down with a $1 \mathrm{ml}$ pipette tip 10 times in $0.05 \%$ DNase in BMEM. In this way, the epithelial sheets were partially dissociated into small pieces containing $\sim 10-80$ cells (Fig. $1 B$ ). Because we found that these cells grew very poorly in serumfree medium, a $5 \%$ fetal bovine serum-supplemented medium was used. Finally, the cell suspension was plated in poly-D-lysine $(500 \mu \mathrm{g} / \mathrm{ml})$-coated 96 well plate (for tritiated thymidine assays) or 16 well Lab-Tek slides (for BrdU labeling and other immunocytochemistry) in $200 \mu \mathrm{l}$ of serumcontaining medium (DMEM plus $5 \%$ fetal bovine serum, $4.5 \mathrm{mg} / \mathrm{ml}$ glucose, $2 \mathrm{~mm}$ glutamine, $25 \mathrm{ng} / \mathrm{ml}$ fungizone, and $10 \mathrm{U} / \mathrm{ml}$ penicillin) at a density of $\sim 70$ cells $/ \mathrm{mm}^{2}$. Typically, cells prepared from four litters of pups (40 P4-P5 rats) were aliquoted equally into 80 wells.

Growth factors. To examine possible effects of growth factors on proliferation of the utricular epithelial cells, we added members of the FGF family, including FGF-1, FGF-2, FGF-4, FGF-5, FGF-6, and FGF-7 (R \& D Systems, Minneapolis, MN); IGF-1 and IGF-2 (R \& D Systems); TGF- $\alpha$ (R \& D Systems); EGF (Collaborative Research, Bedford, MA); human recombinant neurotrophins (Genentech, South San Francisco, CA); TGF- $\beta 1$ (Genentech); TGF- $\beta 2$, TGF- $\beta 3$, and TGF- $\beta 5$ (R \& D Systems); activin, inhibin, glial cell-derived neurotrophic factor (GDNF), heregulin, Gas-6, vascular endothelial growth factor (VEGF), ciliary neurotrophic factor (CNTF), leukemia inhibitory factor (LIF), cardiotrophin-1, and c-kit ligand (Genentech); platelet-derived growth factor (PDGF; Life Technologies, Gaithersburg, MD); and retinoic acid (Sigma) to the cultures at the time when the cells were plated. Maximal effects for FGF-2, IGF-1, and TGF- $\alpha$ were seen at $100 \mathrm{ng} / \mathrm{ml}(0.1-100$ $\mathrm{ng} / \mathrm{ml}$ tested), and therefore all growth factors were used at a concentration of $100 \mathrm{ng} / \mathrm{ml}$, except TGF- $\beta 1$, TGF- $\beta 2$, TGF- $\beta 3$, and TGF- $\beta 5$, which were tested at $1 \mathrm{ng} / \mathrm{ml}$, and neurotrophins at $20 \mathrm{ng} / \mathrm{ml}$ (Zheng et al., 1995a). The concentration of retinoic acid was $10^{-8}$ M (Kelley et al., 1993).

DNA synthesis assays. To measure DNA synthesis, we added ${ }^{3} \mathrm{H}-$ thymidine ( $2 \mu \mathrm{Ci} /$ well) for $24 \mathrm{hr}$ at the $24 \mathrm{th} \mathrm{hr}$ of culture, and cells were harvested with a Tomtec cell harvester. Because the epithelial cells were grown on a poly-L-lysine substrate, trypsin $(1 \mathrm{mg} / \mathrm{ml})$ was added to the culture wells for $25 \mathrm{~min}$ at $37^{\circ} \mathrm{C}$ to lift the cells before cell harvest. Then $\mathrm{cpm} /$ well were counted with a matrix 9600 gas counter (Packard Instrument Company, Meriden, CT) as described previously (Gao et al., 1995). Data were collected from 5 or 10 culture wells from each of the experimental groups and expressed as mean \pm SEM. A two-tailed, unpaired $t$ test was used for statistical analysis.

Bromodeoxyuridine (BrdU) labeling. BrdU labeling was performed via a previously reported method (Gao et al., 1991). Briefly, after $1 \mathrm{~d}$ in culture, BrdU (1:400; Amersham cell proliferation kit, Arlington Heights, IL) was added to the culture medium for $24 \mathrm{hr}$. The cultures were fixed in $4 \%$ paraformaldehyde $(30 \mathrm{~min})$, treated with $2 \mathrm{~N} \mathrm{HCl}(40 \mathrm{~min})$, and incubated with an anti-BrdU monoclonal antibody (Becton-Dickinson, San Jose, CA) 1:40 in PBS containing $0.1 \%$ Triton X-100 overnight at $4^{\circ} \mathrm{C}$. Then the cultures were processed with a Vector $\mathrm{ABC}$ kit (Vector Laboratories, Burlingame, CA). After diaminobenzidine-peroxidase reaction, the cells were dehydrated with ethanol, cleared in Histoclear (American Histology), and mounted in Permount (Fisher Scientific, Pittsburgh, PA).

Cell counts and quantitation. After $2 \mathrm{~d}$ in culture, BrdU-positive cells were counted from the entire areas of 10 or more culture wells for each of the experimental groups. Data were expressed as mean \pm SEM. A two-tailed, unpaired $t$ test was used for statistical analysis.

Immunocytochemistry and immunohistochemistry. After $2 \mathrm{~d}$ in culture, the cells were fixed in $4 \%$ paraformaldehyde (in $0.1 \mathrm{~m}$ phosphate buffer, $\mathrm{pH}$ 7.4) for $30 \mathrm{~min}$. The preparations were blocked first with a $10 \%$ normal goat serum in $0.1 \%$ Triton X-100 in PBS for $20 \mathrm{~min}$ and then incubated with monoclonal antibodies against vimentin $(10 \mu \mathrm{g} / \mathrm{ml}$, Boehringer Mannheim, Indianapolis, IN), Thy1.1 (1:200, Chemicon, Temecula, CA), neurofilament $200 \mathrm{kDa}(5 \mu \mathrm{g} / \mathrm{ml}$, Boehringer Mannheim), myelin (1:200, Cedarlane, Hornby, Ontario, Canada) and pan-cytokeratin (1:50, Sigma), or rabbit antisera against a tight junction protein (ZO1, 1:200, Zymed, South San Francisco, CA) and GFAP (1:500, Dako, Carpenteria, CA) in PBS containing 3\% normal goat serum and $0.1 \%$ Triton X-100 overnight at $4^{\circ} \mathrm{C}$. FITC-conjugated secondary antibodies (1:200; Cappel, West Chester, PA) were used to reveal the labeling patterns. To examine the staining pattern of F-actin, we incubated the preparations with 0.5 $\mu \mathrm{g} / \mathrm{ml}$ phalloidin-FITC conjugates in PBS for $45 \mathrm{~min}$ at room temperature. To determine whether the cultured cells expressed receptors for growth factors, we used a monoclonal antibody against FGF receptor (1:200, Chemicon) and antisera against IGF-1 receptor $\beta$ (1:100, Santa Cruz Biotech, Tebu, France) and trkA (1:10,000, kindly provided by Dr. L. Reichardt at University of California, San Francisco, CA) as primary antibodies. FITC-conjugated secondary antibodies (1:200, Cappel) were used to reveal the staining patterns. For immunohistochemistry, P5 rat utricles were fixed in $4 \%$ paraformaldehyde in $0.1 \mathrm{M}$ phosphate buffer $(\mathrm{pH}$ 7.4) for $1 \mathrm{hr}$. The preparations were rinsed in PBS, cryoprotected in $30 \%$ sucrose solution, and embedded in OCT. Twenty-five micrometer sections were cut and collected on a cryostat machine. Then the sections were immunostained with a monoclonal antibody against FGF-2 $(3 \mu \mathrm{g} /$ ml; UBI, Lake Placid, NY) with a Vector ABC kit (Vector Laboratories) (see Gao et al., 1995). Negative controls were performed by skipping the primary antibody step. The preparations were viewed with a Zeiss Axiophot microscope (Oberkochen, Germany).

Inhibition of cell proliferation by neutralizing antibodies against growth factors. Partially dissociated P4-P5 rat utricular sheets were plated in poly-L-lysine $(500 \mu \mathrm{g} / \mathrm{ml})$-coated 96 well plate in $100 \mu \mathrm{l}$ of $1 \%$ FBSsupplemented medium. Anti-FGF-2 (20 $\mu \mathrm{g} / \mathrm{ml}, \mathrm{UBI})$, anti-IGF-1 (40 $\mu \mathrm{g} / \mathrm{ml}, \mathrm{UBI})$, anti-TGF- $\alpha(20 \mu \mathrm{g} / \mathrm{ml}, \mathrm{R} \& \mathrm{D}$ Systems $)$, or anti-CNTF (20 $\mu \mathrm{g} / \mathrm{ml}, \mathrm{R} \& \mathrm{D}$ Systems) neutralizing antibody was added to the culture at the time of plating. ${ }^{3} \mathrm{H}$-Thymidine $(1 \mu \mathrm{Ci} /$ well $)$ was added for $24 \mathrm{hr}$ at the $24 \mathrm{th} \mathrm{hr}$ of culture, and cells were harvested as described above.

\section{RESULTS}

\section{Cultured utricular epithelial cells express features of epithelial cells, but not those of fibroblast, glial, or neuronal cells}

Modified from a previously reported method (Corwin et al., 1995), utricular epithelial sheets (Fig. $1 A$ ) were separated, partially dissociated, and plated on a poly-D-lysine substrate (Fig. $1 B$ ). Although most isolated single cells died after $2 \mathrm{~d}$ in culture, the cell clumps containing $\sim 10-80$ cells survived well and grew in 

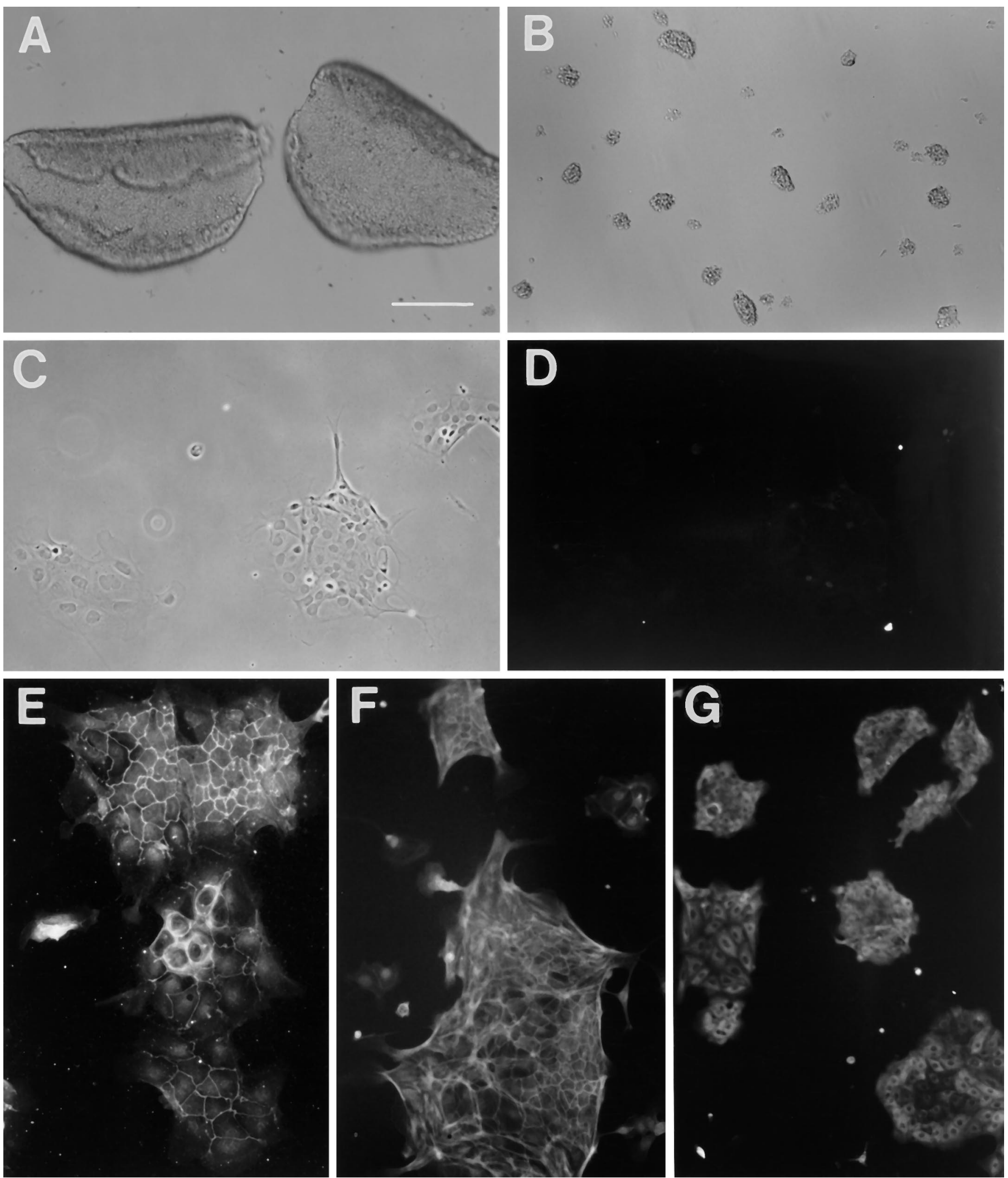

Figure 1. Utricular epithelial cell cultures and immunostainings. $A$, Two intact utricular epithelial sheets separated from P4-P5 rats. $B$, Partially dissociated epithelial sheets at the time of plating. $C, D$, Phase and fluorescence pictures of a $2 \mathrm{~d}$ epithelial cell culture labeled with an antibody against vimentin. $E-G$, Immunostaining of the $2 \mathrm{~d}$ cultures with an antibody against ZO1, a phalloidin-FITC conjugate, and an antibody against pan-cytokeratin, respectively. Scale bars: $A, B, 200 \mu \mathrm{m} ; C-G, 100 \mu \mathrm{m}$. 
Table 1. Immunocytochemical characterization of the cultured utricular
epithelial cells

Markers Immunopositivity

General epithelial cell antigens

ZO1 (Tight junction protein)

F-actin

Cytokeratin

Fibroblast antigens

Vimentin

Thy 1.1

Glial cell antigens

GFAP

Myelin (oligodendrocyte antigen)

Neuronal antigen

$\mathrm{NF}$

Utricular epithelial cells were prepared from P4-P5 rats and plated in poly-D-lysinecoated 16-well Lab-Tek culture slides in 5\% FBS-supplemented medium for $48 \mathrm{hr}$. The cultures were fixed with $4 \%$ paraformaldehyde and then were stained with a phalloidin-FITC conjugate or the antibodies listed above.

patches in the serum-supplemented medium (Fig. $1 C$ ). Immunocytochemical staining with different types of cell markers revealed that these cultured cells expressed epithelial cell antigens, including a tight junction protein (ZO1, Fig. $1 E$ ), F-actin (Fig. $1 F)$, and cytokeratin (Fig. 1G). They did not express antigens for other types of cells, such as glial filament protein (GFAP), the oligodendrocyte antigen (myelin), neurofilament protein, or fibroblast antigens, vimentin (Fig. 1C,D) and Thy1.1. These results are summarized in Table 1 and suggest that the cultured cells are pure epithelial cells. As revealed by phalloidin staining (Fig. $1 F$ ), few stereociliary bundle-bearing cells (hair cells) were seen, suggesting that majority of the hair cells were injured and that many of them might be dead after $2 \mathrm{~d}$ in culture under the present culture conditions. At present, we do not have specific markers for hair cells or supporting cells. Because the utricular epithelial sheets contained mainly supporting cells and hair cells, the vast majority of the surviving cells in the cultures represented a population of utricular supporting cells.

\section{Several FGF family members, IGF-1, IGF-2, TGF- $\alpha$, and EGF, stimulate the proliferation of cultured utricular epithelial cells}

To examine whether any of the presently known growth factors stimulate proliferation of the utricular supporting cells, we measured DNA synthesis by using tritiated thymidine incorporation assays. Under control culture conditions, a moderate level of thymidine uptake was detected. When several FGF family members, including FGF-2, FGF-4, FGF-6, and FGF-7, were added to the culture, a significant elevation in thymidine uptake was seen ( $p<0.05$; Fig. 2). Among them, FGF-2 was the most potent mitogen. In contrast, FGF-1 and FGF-5 did not show a significant effect ( $p>0.05$; Fig. 2). Inclusion of IGF-1 and IGF-2 in the cultures also significantly increased thymidine incorporation $(p<$ 0.05). As positive controls, we added TGF- $\alpha$ or EGF, two previously reported mitogens for the supporting cells (Lambert, 1994; Yamashita and Oesterle, 1995), to the cultures. DNA synthesis was enhanced $\sim 1$.7-fold and 1.5-fold by TGF- $\alpha$ and EGF, respectively (Fig. 2).

To determine whether the elevation in the thymidine uptake reflected an increase in number of dividing cells, we performed BrdU immunocytochemistry. As shown in Figure 3, a much

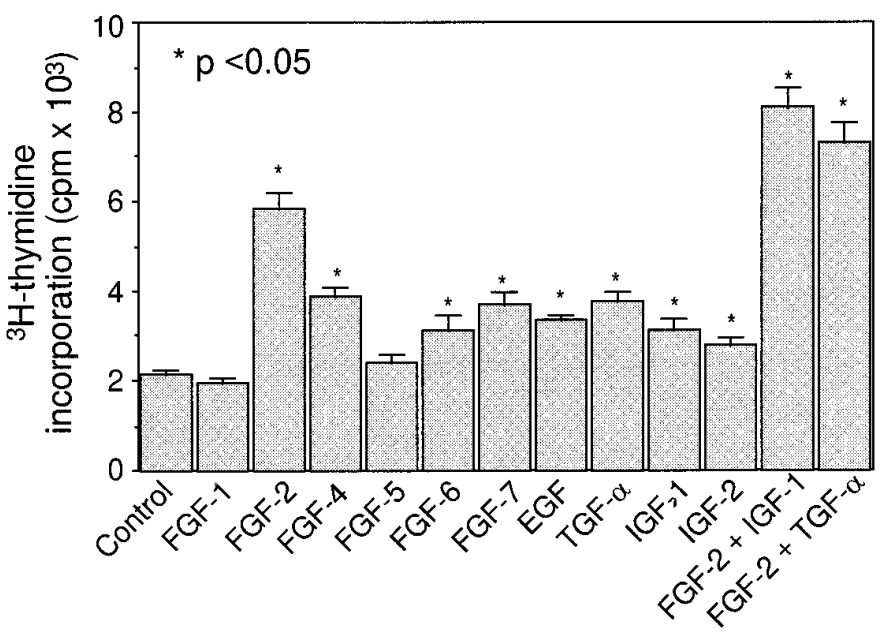

Figure 2. Tritiated thymidine incorporation by P4-P5 utricular epithelial cells. In each case, an identical volume of suspended cells was plated in 5\% fetal bovine serum-supplemented medium in the presence or absence of $100 \mathrm{ng} / \mathrm{ml}$ growth factors. ${ }^{3} \mathrm{H}$-Thymidine was added $24 \mathrm{hr}$ after plating, and the incorporation was measured $24 \mathrm{hr}$ later. Data collected from 5 or 10 culture wells are expressed as mean \pm SEM. Asterisks indicate a significant increase in the thymidine incorporation, as compared with the control cultures $(p<0.05)$. Relative to cultures containing FGF-2 alone, a combination of FGF-2 with IGF-1 or TGF- $\alpha$ resulted in a significantly higher thymidine incorporation $(p<0.05)$.

greater number of BrdU-positive cells were seen in the cultures containing FGF-2. Cell counts performed from the control cultures and cultures containing $100 \mathrm{ng} / \mathrm{ml} \mathrm{FGF-2} \mathrm{confirmed} \mathrm{that}$ FGF-2 significantly enhanced proliferation of the utricular supporting cells $(p<0.01$; Table 2$)$. A significantly higher number of BrdU-positive cells also were seen in the cultures containing 100 ng/ml IGF-1 $(p<0.05)$ or TGF- $\alpha(p<0.01)$, as compared with the control cultures (Table 2).

\section{FGF-2 is a more potent mitogen than IGF-1 or TGF- $\alpha$}

To compare the potency of FGF-2 to IGF-1 and TGF- $\alpha$, we performed a dose-dependent study in the utricular epithelial cell cultures at a range of $0.1-100 \mathrm{ng} / \mathrm{ml}$ (Fig. 4). At a concentration of $0.1 \mathrm{ng} / \mathrm{ml}$, none of the three growth factors showed a detectable effect $(p>0.05)$. At a concentration of $1 \mathrm{ng} / \mathrm{ml}$, FGF-2 displayed a significant mitogenic effect $(p<0.01)$, whereas IGF-1 and TGF- $\alpha$ had no detectable effect. At higher doses $(10-100 \mathrm{ng} / \mathrm{ml})$, all three growth factors showed significant mitogenic effects $(p<$ 0.05 ), as compared with the control cultures. However, FGF-2 was more potent than IGF-1 or TGF- $\alpha$ ( $p<0.01$, Fig. 4). The higher potency of FGF-2 than for that of IGF-1 or TGF- $\alpha$ also was observed with BrdU immunocytochemistry (Table 2).

To determine whether FGF-2 and IGF-1 or TGF- $\alpha$ act synergistically, we added FGF-2 to the cultures, together with either IGF-1 or TGF- $\alpha$. Both tritiated thymidine incorporation and BrdU immunocytochemistry confirmed that combinations of FGF-2 and IGF-1 or FGF-2 and TGF- $\alpha$ resulted in a significantly higher cell proliferation ( $p<0.05$; Fig. 2 and Table 2).

\section{Neurotrophins and other growth factors examined do not promote the proliferation of cultured utricular epithelial cells}

In addition to the FGF family members, IGF-1, IGF-2, TGF- $\alpha$, and EGF, many other growth factors have been reported to influence cell proliferation and differentiation. These include neu- 


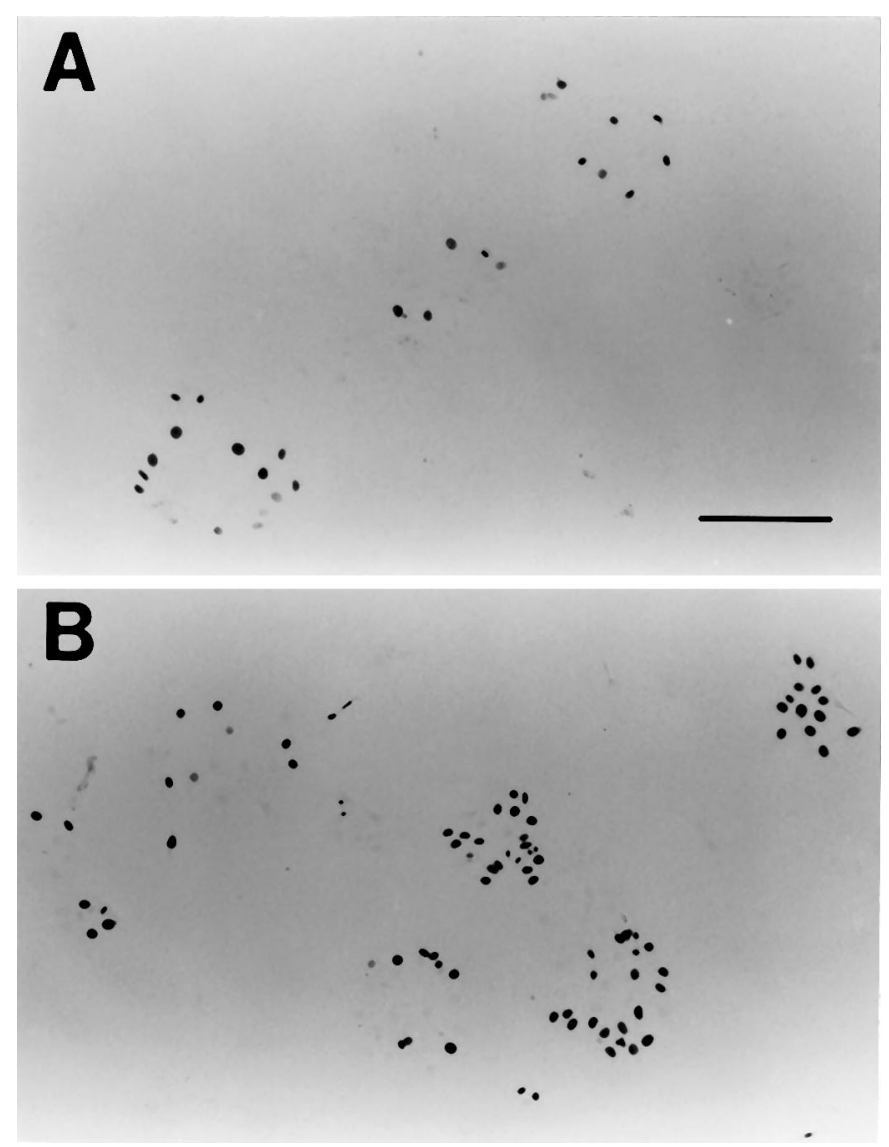

Figure 3. BrdU immunocytochemistry of the utricular epithelial cell cultures. $A$, A control culture. $B$, A culture containing $100 \mathrm{ng} / \mathrm{ml}$ of FGF-2. BrdU was added at $24 \mathrm{hr}$ of culture, and the cultures were fixed at $48 \mathrm{hr}$ for immunocytochemistry. Note that the presence of FGF-2 greatly enhanced the number of BrdU-positive cells. Scale bar, $200 \mu \mathrm{m}$.

rotrophins, the TGF- $\beta$ superfamily, glial cell mitogens such as heregulin and Gas-6, endothelial cell mitogens such as VEGF, and others listed in Table 3. When examined in these cultures, none of the above-mentioned growth factors showed detectable mitogenic effects $(p>0.05)$ on the utricular epithelial cells (Table $3)$. In fact, TGF- $\beta 1$, TGF- $\beta 2$, TGF- $\beta 3$, and TGF- $\beta 5$ showed a $30-67 \%$ inhibition of cell proliferation.

\section{Cultured utricular epithelial cells express FGF receptor and IGF-1 receptor}

To provide further evidence that FGF family members and IGF-1 act directly on these epithelial cells, we did immunostaining using antibodies against FGF receptor and IGF-1 receptor on both utricular sections and the cultured epithelial cells prepared from P4-P5 rats. Although immunoreactivity was low in the sensory epithelium of the utricular sections (data not shown), many of the cultured utricular epithelial cells expressed high levels of the FGF receptor (Fig. 5A,B) and the IGF-1 receptor (Fig. 5C,D), presumably attributable to deprival of hair cells. In contrast, antiserum against TrkA, a high-affinity receptor for NGF, did not stain the cultured cells (Fig. 5E,F). These results suggest that the mitogenic effects of FGFs and IGF-1 are likely through activation of their highaffinity binding receptors on these cultured cells.
Table 2. Cell counts of BrdU-positive cells in the utricular epithelial cell cultures

Experimental groups BrdU-positive cells/culture

\begin{tabular}{lc}
\hline Control & $218 \pm 29$ \\
FGF-2 & $795 \pm 32^{* *}$ \\
IGF-1 & $367 \pm 30^{*}$ \\
TGF- $\alpha$ & $421 \pm 16^{* *}$ \\
FGF-2 + IGF-1 & $940 \pm 47^{* *}$ \\
FGF-2 + TGT- $\alpha$ & $1051 \pm 40^{* *}$
\end{tabular}

Utricular epithelial cells were prepared from P4-P5 rats and cultured in poly-Dlysine-coated 16-well Lab-Tek culture slides in control medium or in medium containing FGF-2, TGF- $\alpha$, IGF-1, or a combination of FGF-2 and TGF- $\alpha$ or IGF-1 at a concentration of $100 \mathrm{ng} / \mathrm{ml}$ for $48 \mathrm{hr}$. BrdU was added at the $24 \mathrm{th} \mathrm{hr}$ of the culture for $24 \mathrm{hr}$. The cultures were fixed with $4 \%$ paraformaldehyde and then were immunostained with antibodies against BrdU. Cell counts of BrdUpositive cells were performed as described in Materials and Methods. Data collected from 10 or more cultures for each of the experimental groups are expressed as mean \pm SEM.

As compared with the control cultures, ${ }^{*} p<0.05$; ${ }^{*} p<0.01$. The cultures containing both FGF-2 and IGF-1 or FGF-2 and TGF- $\alpha$ show a significantly higher number of BrdU-positive cells than the cultures containing FGF-2 alone $(p<0.05)$.

\section{Utricular hair cells produce FGF-2 in vivo}

To determine whether FGF-2 is physiologically present in the utricle, we performed immunohistochemistry with a monoclonal antibody recognizing FGF-2 on P5 rat utricular sections. As shown in Figure 6, hair cells, but not supporting cells, in the utricular sensory epithelium expressed a moderate level of FGF-2. Such immunoreactivity was absent in the basement membrane and the underlying connective tissues. The FGF-2 antibody labeling was specific, because no staining was seen when the utricular sections were incubated with only the secondary antibody. The in vivo expression of FGF-2 by hair cells in the utricular sensory epithelium suggests that FGF-2 is a physiological growth factor.

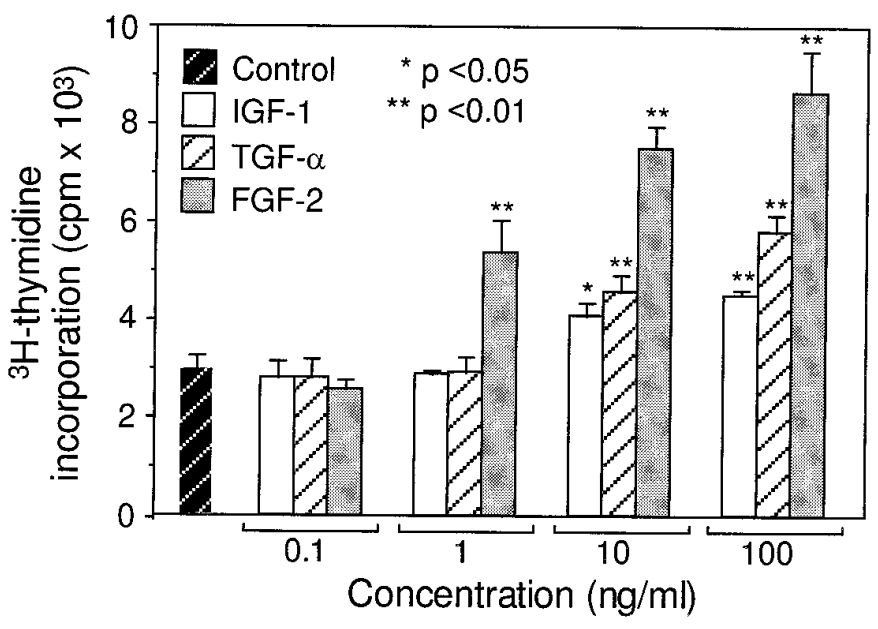

Figure 4. Dose-dependent mitogenic effects of FGF-2, IGF-1, and TGF- $\alpha$. As described in Figure $2,{ }^{3} \mathrm{H}$-thymidine incorporation assay was performed in the cultures containing FGF-2, IGF-1, and TGF- $\alpha$ at concentrations ranging from 0.1 to $100 \mathrm{ng} / \mathrm{ml}$ and in the control cultures. ${ }^{*} p<$ 0.05 and ${ }^{*} p<0.01$, as compared with the control cultures. Relative to IGF-1 and TGF- $\alpha$, FGF-2 was more potent at concentrations ranging from 1 to $100 \mathrm{ng} / \mathrm{ml}(p<0.01)$. 
Table 3. Tritiated thymidine incorporation in the utricular epithelial cell cultures containing different growth factors

\begin{tabular}{|c|c|}
\hline Experimental groups & cpm/culture (mean $\pm \mathrm{SEM})$ \\
\hline Control & $2461 \pm 215$ \\
\hline \multicolumn{2}{|l|}{ Neurotrophins } \\
\hline NGF & $2056 \pm 106$ \\
\hline BDNF & $2352 \pm 227$ \\
\hline NT-3 & $2259 \pm 211$ \\
\hline NT-4/5 & $2296 \pm 126$ \\
\hline \multicolumn{2}{|c|}{ TGF- $\beta$ superfamily members } \\
\hline TGF- $\beta 1$ & $1524 \pm 73$ \\
\hline TGF- $\beta 2$ & $1729 \pm 115$ \\
\hline TGF- $\beta 3$ & $929 \pm 126$ \\
\hline TGF- $\beta 5$ & $807 \pm 59$ \\
\hline Activin & $2383 \pm 186$ \\
\hline Inhibin & $1959 \pm 183$ \\
\hline GDNF & $2383 \pm 186$ \\
\hline \multicolumn{2}{|l|}{ Schwann cell mitogens } \\
\hline Heregulin & $2854 \pm 179$ \\
\hline Gas-6 & $2588 \pm 95$ \\
\hline \multicolumn{2}{|c|}{ Endothelial cell mitogen } \\
\hline VEGF & $2156 \pm 211$ \\
\hline \multicolumn{2}{|l|}{ Others } \\
\hline PDGF & $2387 \pm 299$ \\
\hline CNTF & $2918 \pm 404$ \\
\hline LIF & $2003 \pm 206$ \\
\hline Cardiotrophin-1 & $2065 \pm 295$ \\
\hline c-kit ligand & $2729 \pm 346$ \\
\hline Retinoic acid & $2466 \pm 297$ \\
\hline
\end{tabular}

Utricular epithelial cells were prepared from P4-P5 rats and plated in poly-D-lysinecoated 96-well plate in control medium or medium containing different growth factors (see Materials and Methods). ${ }^{3} \mathrm{H}$-Thymidine $(2 \mu \mathrm{Ci} /$ well $)$ was added for $24 \mathrm{hr}$ at $24 \mathrm{hr}$ of culture, and cells were harvested using a Tomtec cell harvester. Cpm/well then were counted with a matrix 9600 gas counter, as described in Materials and Methods. Data were collected from five culture wells of each experimental group and are expressed as mean \pm SEM. Note that no factors listed in the table exhibited significant mitogenic effects $(p>0.05)$, although inhibition of cell proliferation was induced by TGF- $\beta$ s $(p<0.05)$.

\section{Neutralizing antibodies against FGF-2 or IGF-1 significantly inhibited utricular epithelial cell proliferation}

To discover whether utricular cell proliferation could be blocked or inhibited by removal of endogenous FGF-2 or IGF-1 in the culture, we added neutralizing antibodies to the cultures. Because these cells grew very poorly in serum-free medium, we plated them in reduced fetal bovine serum (1\%)-supplemented medium. Under these conditions, the utricular epithelial cell proliferation was inhibited significantly by the presence of either anti-FGF-2 or anti-IGF-1 antibodies ( $p<0.01$; Fig. 7). In contrast, neither anti-TGF- $\alpha$ antibody, nor anti-CNTF antibody that served as negative controls, showed any inhibitory effect. The inhibition by anti-FGF-2 or anti-IGF-1 antibodies was partial ( $\sim 25 \%)$, presumably attributable to possible existence of other mitogens such as other FGF members, EGF and IGF-2 (see above), in the culture medium. Nevertheless, these results provide further supporting evidence that there were endogenous FGF-2 and IGF-1 in the culture, which stimulated utricular epithelial cell proliferation. The inhibition of cell proliferation by anti-FGF-2 or anti-IGF-1 antibody was not attributable to a general toxicity, because antiTGF- $\alpha$ and anti-CNTF antibodies did not influence cell proliferation, and the mitogenic activity of TGF- $\alpha$ was not affected in the presence of either anti-FGF-2 or anti-IGF-1 antibodies (Fig. 7).

\section{DISCUSSION}

\section{Pure utricular epithelial cultures as a model of developmental study}

In the present experiments, intact utricular epithelial sheets separated by a combined enzymatic and mechanical method essentially contain only supporting cells and hair cells (Corwin et al., 1995). The epithelial identity of the cultured cells is confirmed by using various specific cell markers. Although these cells express epithelial antigens, including the tight junction protein (ZO1), cytokeratin, and F-actin, they do not express fibroblast antigens, vimentin and Thy1.1, or glial and neuronal antigens. Most of the hair cells (stereociliary bundle-bearing cells) are injured, and many of them are dead after $2 \mathrm{~d}$ in culture, perhaps because of their sensitivity to enzymatic digestion and mechanical trituration. Therefore, these cultures essentially represent a population of utricular supporting cells that are believed to be the progenitors for hair cells (Corwin and Cotanche, 1988; Balak et al., 1990; Rapheal, 1992; Weisleder and Rubel, 1992). These cultures may provide an in vitro system to study proliferation and differentiation of the inner ear supporting cells.

The cultured inner ear epithelial cells seem to require cell-cell contacts with neighboring epithelial cells to survive and proliferate. Initially, we attempted to culture completely dissociated epithelial cells, but virtually all cells died. A requirement of cell-cell contact for the survival and proliferation of epithelial progenitors is not unprecedented and has been observed previously with brain germinal zone progenitor cells (Gao et al., 1991) and E9 rat neuroepithelial cells ( $\mathrm{Li}$ et al., 1996). The fact that proliferation of neuroepithelial cells occurs only within the highly compact CNS ventricular zone in vivo and in the progenitor reaggregates (Gao et al., 1991) or neurospheres (Reynolds and Weiss, 1992) in vitro suggests the existence of a membrane-bound factor for the growth of neuroepithelial cells. Consistent with this idea, membranebound components from a C6 glioma cell line have been shown to be necessary for the proliferation and survival of dissociated, single cortical progenitor cells (Davis and Temple, 1994). In contrast to the organ culture (Warchol and Corwin, 1993), the partially dissociated epithelial cells grow poorly in serum-free medium, suggesting that, in addition to the membrane-bound molecules, soluble factors in the serum also promote the growth of these cells. In support of this notion, a monolayer of fibroblast cells seems to be sufficient to support the growth of completely dissociated chick cochlear epithelial cells (Finley and Corwin, 1995).

It is noted that the utricular epithelium is composed of a central, sensory epithelium and a peripheral, marginal zone (Lambert, 1994). Efforts have been made to collect only the sensory epithelium during dissections. In the initial experiments, however, a small portion of some of the transitional cells located at the border of the sensory epithelium and the marginal zone also might be included, because it is difficult to remove them completely from the small fragile epithelial sheets. Suspension of the partially dissociated epithelial sheets allows us to aliquot these cells evenly into the culture wells. The data we obtained should reflect mainly the proliferation of sensory epithelial cells, although a small portion of the transitional epithelial cells also may contribute to a small extent. Although the epithelial cells from the two domains could be derived from the same precursors (for example, the prosensory cells; see Kelley et al., 1993) during embryogenesis, they may play a different role during hair cell differentiation or regeneration. Presumably, the cells in the sensory epithelium are 

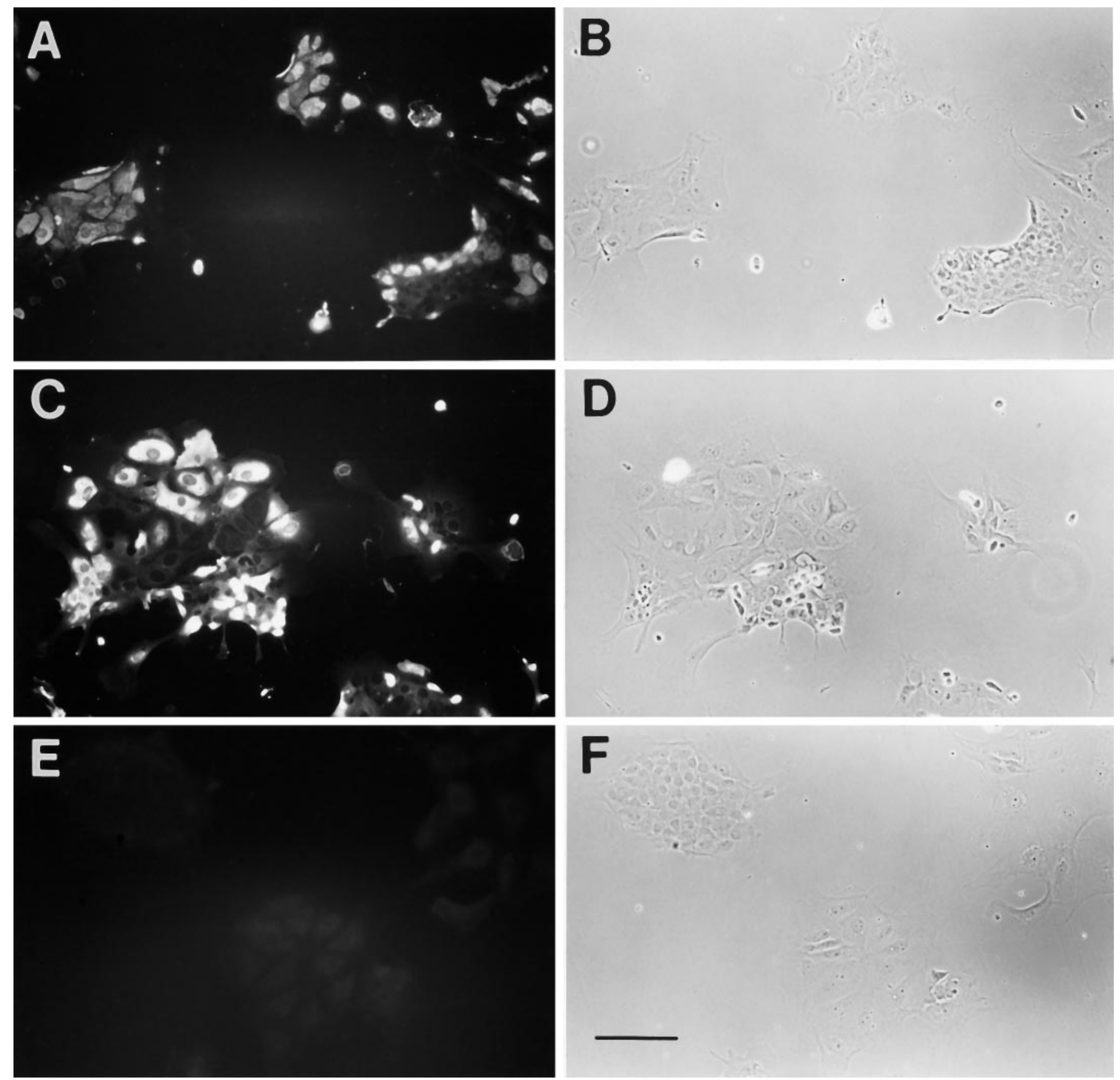

Figure 5. Immunocytochemistry of the utricular epithelial cell cultures with antibodies against receptors for FGF, IGF-1, and NGF. Shown are fluorescence and phase pictures of the $2 \mathrm{~d}$ epithelial cell cultures with antibodies against FGF receptor $(A, B)$, against IGF-1 receptor $\beta(C, D)$, and against TrkA, a high-affinity binding receptor for NGF $(E, F)$. Note that, although many of the cultured cells express high levels of FGF receptor and IGF-1 receptor, no detectable TrkA receptor was observed. Scale bar, $100 \mu \mathrm{m}$.

more differentiated than those in the marginal area, because the central hair cells appear earlier during development than the peripheral hair cells in the utricular sensory epithelium (Sans and Chat, 1982). Nevertheless, previous experiments (Lambert, 1994) have indicated that, on exposure to aminoglycosides or induction by TGF- $\alpha$, equivalent proliferation is observed in both sensory and marginal domains of the utricular epithelium.

In more recent experiments, we have been able to dissect out only the sensory epithelium completely free of the peripheral, nonsensory epithelial cells (although much fewer cells are ob- tained and plated in the culture wells). We have, essentially, obtained the same mitogenic effects of FGF-2, IGF-1, EGF, and TGF- $\alpha$ as in the initial experiments. The cpm of tritiated thymidine incorporation are as follows: control, $671 \pm 92$; FGF-2 treated, $1787 \pm 221$; IGF-1 treated, $1592 \pm 174$; EGF treated, $1168 \pm 130$; and TGF- $\alpha$ treated, $1483 \pm 109$ ( $n=10$ /group). Moreover, in the present study, two previously reported mitogens show positive results, whereas many other growth factors exhibit no mitogenic effects. These internal positive and negative controls provide further support for the validity of our culture system. 


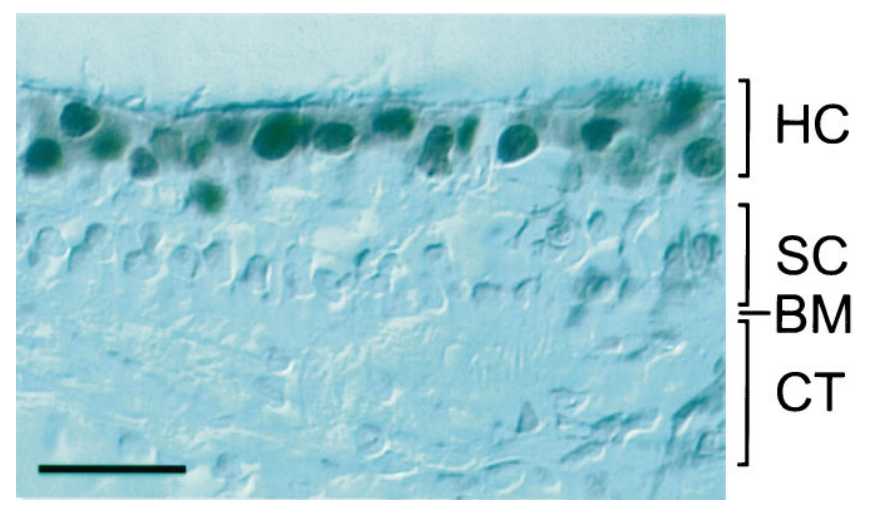

Figure 6. Immunohistochemical labeling of P5 rat utricular sections with a monoclonal antibody recognizing FGF-2. Note that, although hair cells were clearly labeled by the FGF-2 antibody in the apical layer of sensory epithelium, supporting cells in the deep layer of sensory epithelium, basement membrane, and cells in the underlying connective tissues were not labeled. $H C$, Hair cells; $S C$, supporting cells; $B M$, basement membrane; $C T$, connective tissues. Scale bar, $25 \mu \mathrm{m}$.

The pure epithelial cell culture, along with the tritiated thymidine assay, is a rapid and convenient method to evaluate possible effects of growth factors on proliferation of the inner ear epithelial progenitor cells. It allows us to examine a large panel of agents in a relatively short time, and the tritiated thymidine assays are supported by our BrdU immunocytochemistry. In the present experiments we have demonstrated that, among 30 growth factors, several FGF family members, IGF-1, IGF-2, TGF- $\alpha$, and EGF, are mitogenic factors for the proliferation of utricular supporting cells.

The present cultures also may prove to be a good system for directly studying hair cell differentiation as increasing efforts are made toward discovery or development of early hair cell markers (Holley and Nishida, 1995). Understanding the mechanisms for progenitor cell proliferation and hair cell differentiation will be much easier and simpler in the pure utricular epithelial cell culture than in vivo or in the organ culture. For example, it may be possible to use specific inhibitors or activators in these cultures to further dissect the signal transduction pathways of a given growth factor involved in hair cell differentiation.

\section{Mitogenic effects of FGF-2 and IGF-1 on the utricular supporting cells}

Although our observations of the mitogenic effects of TGF- $\alpha$ and EGF are consistent with previous reports (Lambert, 1994; Yamashita and Oesterle, 1995), the results of several FGF family members, IGF-1, IGF-2, and the combination of FGF-2 and TGF- $\alpha$ or IGF-1, are novel. These latter findings are in contrast to a study reported by Yamashita and Oesterle (1995) in the intact organ culture. The simplest interpretation for the discrepancy between these results is that the deprivation of hair cells in the present dissociated utricular epithelial cell cultures might trigger the upregulation of FGF and IGF-1 receptors and enhance the response to FGFs and IGF-1. In support of this explanation, a recent study by Lee and Cotanche (1996) has indicated that damaging chicken cochlear epithelium by noise results in an upregulation of mRNA for the FGF receptor in the supporting cells. Finley and Corwin (1995) reported that FGF-2 promotes the proliferation of chick cochlear supporting

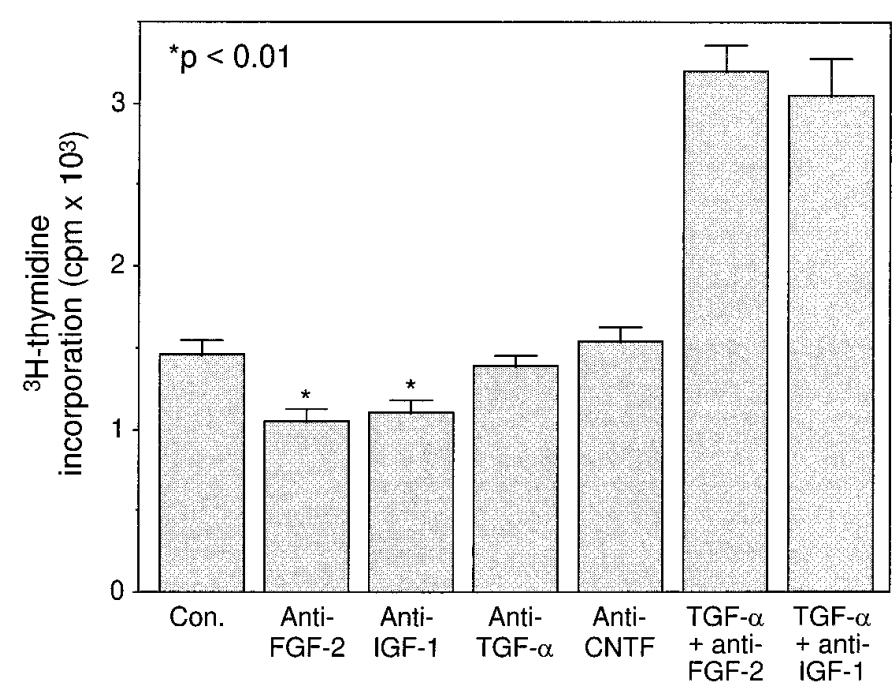

Figure 7. Inhibition of tritiated thymidine incorporation of P4-P5 utricular epithelial cells by anti-FGF-2 or anti-IGF-1 neutralizing antibodies. In each case, an identical volume of suspended cells was plated in $1 \%$ fetal bovine serum-supplemented medium in the presence or absence of antiFGF-2, anti-IGF-1, anti-TGF- $\alpha$, or anti-CNTF antibodies or a combination of TGF- $\alpha(100 \mathrm{ng} / \mathrm{ml})$ and anti-FGF-2 antibody or TGF- $\alpha(100 \mathrm{ng} / \mathrm{ml})$ and anti-IGF-1 antibody. ${ }^{3} \mathrm{H}$-Thymidine was added $24 \mathrm{hr}$ after plating, and the incorporation was measured $24 \mathrm{hr}$ later. Data collected from 10 culture wells are expressed as mean \pm SEM. Note that anti-FGF-2 and anti-IGF-1 antibodies, but not anti-TGF- $\alpha$ and anti-CNTF antibodies, exhibited a significant inhibition, and the mitogenic effect of TGF- $\alpha$ was not influenced by the presence of anti-FGF-2 antibody or anti-IGF-1 antibody.

cells that were dissociated completely and plated on a monolayer of fibroblast cells. The presence of high levels of FGF receptor and IGF-1 receptor in the inner ear epithelial cells after deprivation of hair cells (Lee and Cotanche, 1996; this study) and the inhibition of cell proliferation by neutralizing antibodies against either FGF-2 or IGF-1 (this study) provide additional support for the idea that FGF-2 and IGF-1 act directly on the inner ear supporting cells and induce their proliferation after the removal of hair cells. Considered together, these experiments suggest that FGF-2 and IGF-1 may be candidate molecules regulating proliferation of the inner ear supporting cells, particularly during hair cell regeneration after challenge by aminoglycosides or noise.

Alternatively, there may be a developmental response change to growth factors, including FGF-2 and IGF-1, during maturation of the inner ear epithelium. It is possible that the mature inner ear epithelium responds differently relative to the developing epithelium. Exogenously added FGF-2 or IGF-1 might not elicit a proliferation in the intact, mature utricles (Yamashita and Oesterle, 1995) or in chick tissues that are treated with a very low concentration of aminoglycoside (1 nM; Oesterle et al., 1996) as they would in the immature utricles. On intensive damage by noise or drugs (massive degeneration of hair cells), the immature epithelium might be triggered to go back to an earlier developmental stage. Such injury-induced status shift has been noted for developing neurons (Gao and Macagno, 1988). The present study is performed on postnatal rat inner ear cells that still are undergoing maturation, and thus the possible influence of FGF-2 and IGF-1 on hair cell regeneration after acoustic trauma or exposure to high doses of 
aminoglycosides in adult mammals will have to be addressed in future studies.

It is intriguing that, although several of the FGF family members are mitogenic, FGF-1 and FGF-5 elicit no detectable effects. Because there are at least four various subtypes of FGF receptors and different splicing forms of the receptors (Johnson and Williams, 1993), we do not know, at present, which of the subreceptors mediates the signal transduction pathway. It is particularly interesting to note the lack of an effect by FGF-1, which is present in spiral ganglion and proposed to be a trophic factor for hair cells (Pirvola et al., 1995).

It has been reported previously that IGF-1 stimulates proliferative growth of otic vesicles at the early stages of ontogenesis (Leon et al., 1995). Our study indicates that, in addition, IGF-1 may regulate the development of inner ear epithelium at a slightly later stage-the stage of supporting cell proliferation. Because IGF-1 has been shown to act at multiple stages during the development of neurons, including proliferation (Gao et al., 1991), differentiation, and survival (Neff et al., 1993; Beck et al., 1995), it should be interesting to determine whether it acts also at later stages of hair cell development or works coordinately with other growth factors. In this regard, a preliminary study by Gray et al. (1996) has shown that IGF-1 protects hair cells from aminoglycoside-induced apoptosis. Because IGF-1 receptor is expressed by the cultured utricular epithelial cells (Fig. 5), it is likely that IGF-1 acts on IGF-1 receptor. However, a possibility of crossreaction of IGF-1 through insulin receptor cannot be ruled out, because insulin also elicits a mitogenic effect (data not shown).

\section{Possible physiological role of FGF-2 in hair cell development, maintenance, or regeneration}

The finding that utricular epithelial cells express FGF-2 and its receptor suggests that FGF-2 may be a physiological growth factor for the development, maintenance, and/or regeneration of hair cells. FGF-2 may exert its action via an autocrine mechanism. In this model, FGF-2 produced from hair cells may provide their own trophic support. Recent studies have suggested that cell differentiation and survival in the nervous system can be regulated by a growth factor-mediated autocrine interaction. For instance, colocalization of neurotrophins and their mRNAs is found in developing rat forebrain (Miranda et al., 1993), and a BDNF autocrine loop regulates the survival of cultured dorsal root ganglion cells (Acheson et al., 1995). In this regard, it is interesting to note recent work by Low et al. (1995), which suggests that FGF-2 protects postnatal rat cochlear hair cells from aminoglycosideinduced injury. Alternatively, a paracrine action also might be postulated in which FGF-2 synthesized by hair cells could locally influence maintenance of neighboring hair cells and proliferation of supporting cells. In this case, degeneration of hair cells may lead to a burst release of FGF-2, which would, in turn, stimulate supporting cell proliferation in the inner ear epithelium. The latter hypothesis may explain the supporting cell proliferation after hair cell death attributable to acoustic trauma or exposure to aminoglycosides, because FGF-2 does not have a signal sequence and cell injury is a major way for its release. Our finding that anti-FGF-2 antibody, but not anti-TGF- $\alpha$ antibody, significantly inhibits cell proliferation (Fig. 7) supports this hypothesis to a certain extent. The partial, but not complete, blocking effect by anti-FGF-2 antibody could be attributable to possible existence of other mitogens in the culture, loss of FGF-2 (because of hair cell injury) during the dissociation process, and/or relief from contact inhibition within the epithelium after dissociation.

\section{Neurotrophins and other growth factors}

Neurotrophins, including NGF, BDNF, NT-3, and NT-4/5, are important molecules for the development of the nervous system. In particular, BDNF and NT-3 are reported to be survival factors for spiral and vestibular ganglion neurons in vivo (Ernfors et al., 1994, 1995; Farinas et al., 1994; Bianchi et al., 1995; Fritzsch et al., 1995) and in vitro (Lefebvre et al., 1994; Zheng et al., 1995a,b). These molecules also protect the two types of neurons against ototoxins in culture (Zheng et al., 1995a,b). They are not, however, critical for the survival of hair cells (Ernfors et al., 1995; Fritzsch et al., 1995) and do not protect hair cells against ototoxins (Zheng and Gao, 1996). The present observations indicate that the neurotrophins do not affect the proliferation of the progenitor cells directly, but this does not rule out the possibility that they exert some effect on the later stages of hair cell differentiation. A certain degree of abnormality in the phenotype of type I utricular hair cells and the thickness of the utricular epithelium has been observed in mice lacking both the BDNF and NT-3 genes (Ernfors et al., 1995) or in those lacking both the trkB and trkC genes (Minichiello et al., 1995). In addition, a stage-specific effect of neurotrophins has been illustrated in the development of cerebellar granule cells. There, specific neurotrophins act at a late stage of differentiation, but not at the stage of proliferation (Gao et al., 1995).

Similar to neurotrophins, many other growth factors examined in the present experiments do not show significant mitogenic effects on utricular supporting cells. They could, however, still be involved in later phases of hair cell regeneration. For example, retinoic acid can induce formation of supernumerary hair cells in the developing cochlea without involvement of cell proliferation (Kelley et al., 1993). On the other hand, early differentiating factors might inhibit the progenitor proliferation and push the progenitors to come out of the cell cycle and become postmitotic cells. Regarding this aspect, it is interesting to note, then, that TGF- $\beta 1$, TGF- $\beta 2$, TGF- $\beta 3$, and TGF- $\beta 5$ exhibit an inhibition on the proliferation of the inner ear epithelial cells. Whether such observation implies a possible involvement of TGF- $\beta \mathrm{s}$ in the differentiation of hair cells remains to be determined.

The finding that FGF-2 and IGF-1 or TGF- $\alpha$ have additive mitogenic effects suggests that several growth factors may work in concert during the development of hair cells. For example, FGF-2 and TGF- $\beta 1$ have been shown synergistically to regulate chondrogenesis during otic capsule formation (Frenz et al., 1994). There could be inhibitory signals coming from hair cells that would prevent supporting cell proliferation and induce new hair cell differentiation. It is quite possible that multiple growth factors may contribute together to the differentiation or regeneration of hair cells. They may work either in a sequential manner or at multiple steps. In support of this notion, a preliminary study by Kopke et al. (1996) suggests that a combination of TGF $\alpha$, IGF-1, and retinoic acid can facilitate the utricular hair cell repair or regeneration.

In summary, we have established a purified mammalian utricular epithelial cell culture, which allows us to rapidly examine possible effects of known and novel growth factors on supporting cell proliferation, an early phase during normal development and regeneration of new hair cells. Among the 30 growth factors we examined, FGF-2 is the most potent mitogen. The observation that the inner ear hair cells produced FGF-2 in vivo and utricular epithelial cells expressed FGF 
receptor in vitro suggests a physiological role of FGF-2 in hair cell development, maintenance, or regeneration. Once a specific hair cell marker, particularly an early hair cell marker labeling the entire cell body, is identified, this culture system may prove invaluable for directly studying hair cell differentiation or regeneration. A combined analysis of both aspects of the progenitor cell proliferation and differentiation would be critical to development of treatments to compensate for hair cell loss, a major cause for hearing and balance disorders.

\section{REFERENCES}

Acheson A, Conover JC, Fandl JP, DeChiara TM, Russell M, Thadani A, Squinto SP, Yancopoulos GD, Lindsay RM (1995) A BDNF autocrine loop in adult sensory neurons prevents cell death. Nature 374:450-453.

Adler HJ, Phillips J, Raphael Y (1996) Immunocytochemical evidence for supporting cell conversion in the acoustically damaged chick. Assoc Res Otolaryngol Abstr 19:4.

Anderson DJ (1989) The neural crest cell lineage problem: neuropoiesis? Neuron 3:1-12.

Balak KJ, Corwin JT, Jones JE (1990) Regenerated hair cells can originate from supporting cell progeny: evidence from phototoxicity and laser ablation experiments in the lateral line system. J Neurosci 10:2505-2512.

Beck KD, Powell-Braxton L, Widmer HR, Valverde J, Hefti F (1995) Igf1 gene disruption results in reduced brain size, CNS hypomyelination, and loss of hippocampal granule and striatal parvalbumincontaining neurons. Neuron 14:717-730.

Bianchi LM, Conover J, DeChiara T, Yancopoulos GD, Lindsay RM (1995) Development of auditory and vestibular neurons in mice with a targeted disruption of the BDNF and NT-4 gene. Assoc Res Otolaryngol Abstr 18:108.

Cattaneo E, McKay R (1990) Proliferation and differentiation of neuronal stem cells regulated by nerve growth factor. Nature 347:762-765.

Corwin JT, Cotanche DA (1988) Regeneration of sensory hair cells after acoustic trauma. Science 240:1772-1774.

Corwin JT, Finley JE, Saffer R, Gu R, Cunningham L, Xia B, Warchol M (1995) Isolation of pure living hair cell epithelia by use of thermolysin. Assoc Res Otolaryngol Abstr 18:87.

Cotanche DA (1987) Regeneration of hair cell stereociliary bundles in the chick cochlea following severe acoustic trauma. Hear Res 30:181-196.

Cotanche DA, Lee K (1994) Regeneration of hail cells in the vestibulocochlear system of birds and mammals. Curr Opin Neurobiol 4:509-514.

Davis AA, Temple S (1994) A self-renewing multipotential stem cell in embryonic rat cerebral cortex. Nature 372:263-266.

Ernfors P, Lee K-F, Jaenisch R (1994) Mice lacking brain-derived neurotrophic factor develop with sensory deficits. Nature 368:147-150.

Ernfors P, Van De Water T, Loring J, Jaenisch R (1995) Complementary roles of BDNF and NT-3 in vestibular and auditory development. Neuron 14:1153-1164.

Farinas I, Jones KR, Backus C, Wang X-Y, Reichardt LF (1994) Severe sensory and sympathetic deficits in mice lacking neurotrophin-3. Nature 369:658-661.

Finley JE, Corwin JT (1995) Assessment of growth factor effects on dissociated hair cell progenitors cultured with a feeder layer. Assoc Res Otolaryngol Abstr 18:84.

Forge A, Li L, Corwin JT, Nevill G (1993) Ultrastructural evidence for hair cell regeneration in the mammalian inner ear. Science 259:1616-1619.

Frenz DA, Liu W, Williams JD, Hatcher V, Galinovic-Schwartz V, Flanders KC, Van De Water TR (1994) Induction of chondrogenesis: requirement for synergistic interaction of basic fibroblast growth factor and transforming growth factor-beta. Development (Camb) 120:415-424.

Fritzsch B, Silos-Santiago I, Smeyne R, Fagan AM, Barbacid M (1995) Reduction and loss of inner ear innervation in trkB and trkC receptor knockout mice: a whole-mount DiI and scanning electron microscopic analysis. Auditory Neurosci 1:401-417.
Gao W-Q, Macagno ER (1988) Axon extension and retraction by leech neurons: severing early projections to peripheral targets prevents normal retraction of other projections. Neuron 1:269-277.

Gao W-Q, Heintz N, Hatten ME (1991) Cerebellar granule cell neurogenesis is regulated by cell-cell interactions in vitro. Neuron 6:705-715.

Gao W-Q, Zheng JL, Karihaloo M (1995) Neurotrophin-4/5 (NT-4/5) and brain-derived neurotrophic factor (BDNF) act at later stages of cerebellar granule cell differentiation. J Neurosci 15:2656-2667.

Ghosh A, Greenberg ME (1995) Distinct roles for bFGF and NT-3 in the regulation of cortical neurogenesis. Neuron 15:89-103.

Gray EMG, Warchol ME, Corwin JT (1996) IGF-1 protects hair cells from aminoglycoside-induced apoptotic cell death. Assoc Res Otolaryngol Abstr 19:198.

Holley MC, Nishida Y (1995) Monoclonal antibody markers for early development of the stereociliary bundles of mammalian hair cells. J Neurocytol 24:853-864.

Johnson DE, Williams LT (1993) Structural and functional diversity in the FGF receptor multigene family. Adv Cancer Res 60:1-41.

Jones JE, Corwin JT (1996) Regeneration of sensory cells after laser ablation in the lateral line system: hair cell lineage and microphage behavior revealed by time-lapse video microscopy. J Neurosci 16:649-662.

Kelley MW, Xu XM, Wagner MA, Warchol ME, Corwin JT (1993) The developing organ of Corti contains retinoic acid and forms supernumerary hair cells in response to exogenous retinoic acid in culture. Development (Camb) 119:1041-1053.

Kopke R, Garcia P, Feghali J, Gabaizadeh R, Liu W, Staecher H, Lefebvre PP, Van De Water TR (1996) In vivo treatment with TGF $\alpha$ / IGF-1/retinoic acid mixture increases hair cell regeneration/repair in guinea pig utricles. Assoc Res Otolaryngol Abstr 19:198.

Lambert PR (1994) Inner ear hair cell regeneration in a mammal: identification of a triggering factor. Laryngoscope 104:701-717.

Lee KH, Cotanche DA (1996) Potential role of bFGF and retinoic acid in the regeneration of chicken cochlear hair cells. Hear Res 94:1-13.

Lefebvre PP, Malgrange B, Staecher H, Moghadass M, Van De Water TR, Moonen G (1994) Neurotrophins affect survival and neuritogenesis by adult injured auditory neurons in vitro. NeuroReport 5:865-868

Leon Y, Vazquez E, Sanz C, Vega JA, Mato JM, Giraldez F, Represa J, Varela-Nieto I (1995) Insulin-like growth factor-1 regulates cell proliferation in the developing inner ear, activating glycosylphosphatidylinositol hydrolysis and fos expression. Endocrinology 136:3494-3503.

Li L, Forge A (1996) Morphological evidence for the possibility of direct supporting cell to hair cell conversion in the mature mammalian vestibular sensory epithelium. Assoc Res Otolaryngol Abstr 19:7.

Li R, Gao W-Q, Mather JP (1996) Multiple factors control the proliferation and differentiation of rat early embryonic (day 9) neuroepithelial cells. Endocrine, in press.

Low W, Baird A, Ryan AF (1995) Protection of cochlear hair cells from aminoglycoside injury by basic fibroblast growth factor (FGF-2). Assoc Res Otolaryngol Abstr 18:200.

Minichiello L, Piehl F, Vazquez E, Schimmang T, Hokfelt T, Represa J, Klein R (1995) Differential effects of combined trk receptor mutations on dorsal root ganglion and inner ear sensory neurons. Development (Camb) 121:4067-4075.

Miranda RJ, Farida S, Toran-Allerand CD (1993) Neuronal colocalization of mRNAs for neurotrophins and their receptors in the developing central nervous system suggests a potential for autocrine interactions. Proc Natl Acad Sci USA 90:6439-6443.

Neff NT, Prevette D, Houenou JL, Lewis ME, Glicksman MA, Yin Q-W, Oppenheim RW (1993) Insulin-like growth factors: putative musclederived trophic agents that promote motoneuron survival. J Neurobiol 24:1578-1588.

Oesterle EC, Bhave SA, Coltrera MD (1996) bFGF inhibits cell proliferation in cultured inner ear sensory epithelia. Assoc Res Otolaryngol Abstr 19:198.

Pirvola U, Cao Y, Oellig C, Suoqiang Z, Pettersson RF, Ylikoski J (1995) The site of action of neuronal acidic fibroblast growth factor is the organ of Corti of rat cochlea. Proc Natl Acad Sci USA 92:9269-9273. 
Rapheal Y (1992) Evidence for supporting cell mitosis in response to acoustic trauma in the avian inner ear. J Neurocytol 21:663-671.

Reynolds BA, Weiss S (1992) Generation of neurons and astrocytes from isolated cells of the adult mammalian central nervous system. Science 255:1707-1710.

Ryals BM, Rubel EW (1988) Hair cell regeneration after acoustic trauma in adult Coturnix quail. Science 240:1774-1776.

Sans A, Chat M (1982) Analysis of the temporal and spatial patterns of rat vestibular hair cell differentiation by tritiated thymidine radioautography. J Comp Neurol 206:1-8.

Vicario-Abejon C, Johe KK, Hazel TG, Collazo D, McKay DG (1995) Functions of basic fibroblast growth factor and neurotrophins in the differentiation of hippocampal neurons. Neuron 15:105-114.

Warchol ME, Corwin JT (1993) Supporting cells in avian vestibular organs proliferate in serum-free culture. Hear Res 71:28-36.

Warchol ME, Lambert PR, Goldstein BJ, Forge A, Corwin JT (1993) Regenerative proliferation in inner ear sensory epithelia from adult guinea pigs and humans. Science 259:1619-1622.
Weisleder P, Rubel EW (1992) Hair cell regeneration in the avian vestibular epithelium. Exp Neurol 115:2-6.

Yamashita H, Oesterle EC (1995) Induction of cell proliferation in mammalian inner ear sensory epithelia by transforming growth factor $\alpha$ and epidermal growth factor. Proc Natl Acad Sci USA 92:3152-3155.

Zheng JL, Gao W-Q (1996) Differential damage to auditory neurons and hair cells by ototoxins and neuroprotection by specific neurotrophins in rat cochlear organotypic cultures. Eur $\mathbf{J}$ Neurosci 8:1897-1905.

Zheng JL, Stewart RR, Gao W-Q (1995a) Neurotrophin-4/5 enhances survival of cultured spiral ganglion neurons and protects them from cisplatin neurotoxicity. J Neurosci 15:5079-5087.

Zheng JL, Stewart RR, Gao W-Q (1995b) Neurotrophin-4/5, brainderived neurotrophic factor, and neurotrophin-3 promote survival of cultured vestibular ganglion neurons and protect them against neurotoxicity of ototoxins. J Neurobiol 28:330-340. 